\title{
Article
}

\section{The Impact of Carbon Disclosure on Financial Performance under Low Carbon Constraints}

\author{
Wenting Lu, Naiping Zhu * and Jing Zhang \\ School of Finance \& Economics, JiangSu University, No. 301 Xuefu Road, Jingkou District, \\ Zhenjiang 212013, China; 2112019002@stmail.ujs.edu.cn (W.L.); jzhang2015@163.com (J.Z.) \\ * Correspondence: npzhu@ujs.edu.cn
}

Citation: Lu, W.; Zhu, N.; Zhang, J. The Impact of Carbon Disclosure on Financial Performance under Low Carbon Constraints. Energies 2021, 14, 4126. https://doi.org/10.3390/ en14144126

Academic Editor: Nuno Carlos Leitão

Received: 5 May 2021

Accepted: 5 July 2021

Published: 8 July 2021

Publisher's Note: MDPI stays neutral with regard to jurisdictional claims in published maps and institutional affiliations.

Copyright: (c) 2021 by the authors. Licensee MDPI, Basel, Switzerland. This article is an open access article distributed under the terms and conditions of the Creative Commons Attribution (CC BY) license (https:// creativecommons.org/licenses/by/ $4.0 /)$.

\begin{abstract}
In the context of low-carbon constrained development, in order to avoid the risk brought by climate change, more and more companies choose to disclose carbon information, respond to the national policy of carbon emission reduction and focus on the sustainable development of enterprises. This paper will investigate the impact of carbon disclosure on financial performance based on the 2011-2018 CDP report, taking the Fortune 500 companies as a sample. The study finds that for carbonintensive industries, carbon disclosure cannot significantly contribute to the improvement of financial performance in the current period, but for carbon-non-intensive industries, carbon disclosure can significantly contribute to the improvement of financial performance in the current period, and the positive impact of carbon disclosure on financial performance in the current period can be extended to the next period. Finally, based on the findings of the empirical study, this paper puts forward policy recommendations for the construction of China's carbon disclosure system.
\end{abstract}

Keywords: fortune 500; carbon disclosure; financial performance

\section{Introduction}

Greenhouse gas (GHG) emissions have become one of the primary threats to the existence of life on earth. The excessive GHGs in the earth's atmosphere led to undesirable consequences in the ecosystem, creating global warming or climate change (Liu et al. Sand) [1,2]. Since 1880, the global average temperature has risen by $0.85{ }^{\circ} \mathrm{C}$ according to the data from Intergovernmental Panel on Climate Change (IPCC) [3]. As the Climate Change 2013 predicted, by 2100, the world will face a rise of the ground temperature and an increase in carbon dioxide concentration, and the sea level will rise by 26 to $81 \mathrm{~cm}$. The main reason for climate warming is most likely (95\%) that we did not aggressively reduce carbon emissions. By the end of this century, global warming will exceed $2{ }^{\circ} \mathrm{C}$, or may exceed $4{ }^{\circ} \mathrm{C}$ according to the Climate Change 2013 report [3]. At present, according to the Intergovernmental Panel on Climate Change (IPCC) special report on the impacts of global warming of $1.5^{\circ} \mathrm{C}$, the control of greenhouse gas (GHG) emissions has become a necessary condition for companies to achieve sustainable development and it is important to limit the global warming of $1.5^{\circ} \mathrm{C}[4]$ and therefore, there is an increasing demand for carbon disclosure in society.

More and more climate events dominate the headlines of the media, and they have a major impact on the economic development of various countries all over the world. On 15 January 2020, the World Economic Forum (WEF) released the Global Risks Report 2020. The report presents the main risks the world facing in the coming year, pointing out that all five major global risks in 2020 are environmental risks, while climate change is the biggest risk facing the world in 2020 [5]. In this context, a series of new concepts and policies such as "low-carbon economy", "low-carbon development" and "low-carbon city" have emerged. Low-Carbon Economy has attracted people's attention in recent years. It is a business model based on low energy consumption, low pollution, and low emissions, which will guide the "Fourth Industrial Revolution", protect the existence of non-renewable 
energy, prevent global warming, realize sustainable economic development, and at the same time create a healthy and green home for people.

On 12 December 2015, 195 countries and the European Union unanimously agreed to adopt the "Paris Agreement" at the Paris Climate Change Conference, opening a new chapter for taking action on global climate change. In order to control carbon emissions, countries around the world have committed to emission reduction targets and have formulated policies and regulations to regulate and guide the carbon emission reduction behavior of enterprises. It has become an inevitable choice to take a low-carbon economy. As a consequence of stakeholders starting exerting started exerting pressure on corporations to decrease their GHG emissions, firms are now likely to play a vital role in reducing their GHG emissions and contributing to stabilizing climate change (Luo) [6]. In recent years, firms have been asked to disseminate information about climate change related activities, also referred to as carbon disclosures, to satisfy the concerns of relevant stakeholders (Li et al., Meng et al.) [7,8]. Under the emission reduction pressures in the world, China should need to change the current high energy-consuming and high-pollution development model, accelerate the adjustment of economic structure, promote technological progress, and improve energy efficiency [9]. Although various countries have introduced various laws and regulations on carbon emissions and policies to encourage carbon emission reduction, and researchers have also realized the importance of carbon disclosure, there are still some people who question the authenticity of this information because of the inherent uncertainty between measurement of carbon emissions and carbon emissions reduction. In the case of internationally recognized standards, CDP (Carbon Disclosure Project) adopts a unique set of rules that all participating companies must follow, which greatly reduces the opportunity for managers to manipulate carbon data. Liu believes that carbon information disclosure by enterprises is an effective way to improve social awareness of low carbon and environmental protection, and a good carbon information disclosure mechanism helps internal and external stakeholders to have a better understanding of corporate low carbon governance and strengthen the carbon regulation of government departments [10]. The study of carbon disclosure has been gaining increasing importance in recent years to help firms communicate their climate change activities to their stakeholders through environment disclosures (Hahn et al., Uyar et al.) [11,12]. With the deepening of low-carbon economy in China, the demand for carbon information from the market and corporate stakeholders is increasing. The relationship between the quality of carbon information and the performance of enterprises can be explored by evaluating the carbon information disclosed by enterprises. The relationship between the quality of carbon information disclosed by enterprises and their own performance is particularly important to motivate enterprises to disclose their carbon information. To this end, this paper will investigate the impact of carbon disclosure on financial performance based on the 2011-2018 CDP report, taking the Fortune 500 companies as a sample. Based on existing research perspectives, this paper uses the scoring index and carbon emission data from the CDP report, as well as the financial data of enterprises to investigate the relationship between carbon disclosure and financial performance of carbon-intensive companies and carbon-non-intensive companies. This paper takes voluntary disclosure theory, legitimacy theory, stakeholder interest theory, signaling theory, and sustainable development theory as its pillars, and applies them to the research fields of carbon disclosure and financial performance, and conducts a profound analysis on the theoretical level.

The paper deepens the understanding of carbon disclosure by enterprises from the theoretical level, which has certain significance for the practice of carbon disclosure of Chinese enterprises, and also promotes the development of empirical research related to carbon disclosure. At the same time, the empirical research in this paper also makes up for the deficiencies of existing research as few scholars have studied whether the significant impact of carbon disclosure on financial performance is deferred to the next period and few scholars have conducted comparative analysis of for carbon-intensive industries and carbon-non-intensive industries. Therefore, this research will investigate the impact of 
carbon disclosure on current financial performance for carbon-intensive industries and carbon-non-intensive industries, and on this basis, the intertemporal impact of carbon disclosure on financial performance.

\section{Literature Review and Theoretical Hypotheses}

\subsection{Literature Review}

Many scholars have found that, as both sides of a transaction, companies disclose carbon information so that stakeholders can have sufficient information to facilitate the formation of the transaction and promote the enhancement of corporate value. The earliest environmental information study had been included in social responsibility information to conduct relevant studies and environmental information disclosure were mostly at the level of theoretical and descriptive analysis (Mobley; Gray et al.) [13,14]. Friedman conducted a study on the relationship between social responsibility and corporate performance [15]. With the research on the determinants of social responsibility and environmental information disclosure (Deegan, Gordon; Karim et al.) $[16,17]$ and the continuous research on economic consequences and market reactions (Dhaliwal et al.; Lys et al.) $[18,19]$. In recent years, the research on social responsibility information and environmental information disclosure has also been refined. Scholars have been studying the disclosure of social responsibility information and environmental information from internal and external perspectives, and from the perspective of report forensics respectively [20].

Most of the early studies on the relationship between carbon disclosure and corporate financial performance showed a negative relationship, validating the views of traditional economists and neoclassical schools. Hassel combined research with the cost-related theory and pointed out that the cost of disclosing carbon information in the process of maintaining the legitimacy of enterprises is greater than the benefit, and the more detailed and comprehensive the carbon information disclosure, the more costly it is, the carbon information disclosure will negatively affect the enterprise's interest goal, and the quality of disclosure is negatively related to the enterprise's value. There is a negative relationship between disclosure quality and corporate value, and carbon information disclosure will reduce the financial performance of enterprises [21]. Chapple et al. also verified that the expensive cost of carbon disclosure by firms to gain legitimacy outweighs the benefits of the act, and that corporate carbon management practices can cause changes in firm value [22]. Griffin et al. found that due to the high cost of disclosure, carbon information disclosure does not bring economic benefits to firms or even reduces their profitability [23].

According to the theory of information asymmetry, carbon information is an important non-financial information for investors' decision making, and high-quality carbon information disclosure can effectively improve the situation of information disadvantage for investors. The disclosure of high-quality carbon information can effectively improve the situation that investors are at an information disadvantage, and to a certain extent can reduce the risk faced by investors and protect the interests of investors. At the same time, enterprises can get the necessary resources for production and operation. Proactive disclosure of carbon information is the most important way for companies to gain access to stakeholders and achieve their sustainable development. Saka and Oshika pointed out that carbon information disclosure has a positive impact on market-based financial performance [24]. Velte et al. found that carbon performance was significantly associated with carbon disclosure, and carbon information disclosure can reduce information asymmetry, while carbon information disclosure can increase financial performance [25]. Although carrying out carbon emission reduction and disclosing carbon information will incur certain costs, failure to fulfill carbon emission reduction obligations and disclose related information may save enterprises some costs in the short term, but in the long term development will generate more explicit or implicit costs, affect the efficiency of resource allocation of enterprises, cause implicit harm to enterprises, which in turn affects their competitiveness and hinders the improvement of enterprise value and performance. Lemma et al. stated that firms can meet consumer expectations by reducing their carbon 
footprint and can reasonably expect that after meeting consumer expectations company can obtain from existing or potential customers [26]. Lueg state that disclosure hardly affects financial performance by changing free cash flow, but the increase in transparency from high quality disclosure can reduce information asymmetry between stakeholders and impact on financial performance by reducing risk [27].

According to signaling theory, carbon information disclosure can alleviate the pressure that companies may face and increase stakeholders' corporate recognition and support, which in turn promotes financial performance. Companies that are aware of the environmental crisis, when they are aware of the environmental crisis, they will immediately take measures to minimize the risk of environmental pollution and protect their reputation and image by disclosing information. This can reduce financial risk to a certain extent. Wegener empirically examined the impact of corporate disclosure of carbon information on the stock market based on CDP reports of Canadian companies and found that voluntary disclosure of carbon information increased shareholder motivation and reduced transaction costs, which in turn had a positive impact on stock market value [28]. Ziegler et al. and Schiager found that for U.S. energy companies, in response to pressure from global warming agencies to gain legitimacy, companies actively disclose their efforts to respond to climate change, enhance their corporate image and thus significantly improve their stock performance $[29,30]$. Saka and Oshika studied the relationship between carbon disclosure and equity market value of more than 1000 companies in Japan based on circumventing sampling bias and endogeneity issues and found that their equity market value increases as the content of carbon disclosure increases [24]. Ganda selected a sample of South African companies as a study and examined the impact of carbon emission reporting on financial value and found that carbon disclosure was positively correlated with accounting-based indicator Return on Assets (ROA) in most cases but negatively correlated with market-based indicator Market Value Added (MVA) by conducting panel regressions on the data of the sample companies from 2010-2015 [31]. Iskandar and Fran found that carbon emissions disclosure significantly negatively affects firm value and corporate social responsibility disclosure significantly positively affects firm value [32]. Siddique et al. examined how carbon performance affects carbon disclosure and how carbon disclosure affects financial performance and the results showed that carbon disclosure positively affects carbon performance, consistent with the signaling theory. It also showed that carbon disclosure negatively affects financial performance in the short-term, and positively affects financial performance in the long-term [33].

Some scholars have studied the possible economic impact of carbon information disclosure from the perspective of corporate governance. Carbon information disclosure is a rational choice for firms, and Schiager and Haukvik selected Nordic listed companies in the CDP report as the research object and studied the mechanism of carbon information disclosure affecting company value from both accounting and marketing perspectives, respectively, and found that carbon information disclosure by listed companies can enhance corporate value [30]. Borghei et al. analyzed the annual reports of Australian firms and found that the return on corporate assets increased in the year following carbon information disclosure, noting that carbon information disclosure positively affects corporate financial performance [34]. Brouwers et al. stated that carbon performance and information disclosure have a positive impact on corporate financial performance in the long run [35].

Based on the perspective of environmental information disclosure, many scholars' studies show that there is a positive relationship between environmental information disclosure and financial performance of enterprises. Freedman and Jaggi found that environmental disclosure in the petroleum industry shows a significant positive relationship with financial performance [36]. Murray et al. separated environmental information from social responsibility information in a separate study and found a positive relationship between the quality of environmental disclosure of many UK firms and their contemporaneous returns [37]. Anderson et al. concluded similarly that companies with good business performance have a correspondingly higher quality of environmental information 
disclosure [38]. Stanwick and Stanwick studied 469 listed companies in the 1994 Forbes 500 and found that the financial performance of the different groupings of high medium, low had different effects on the response to the environment, with high financial performance companies having a higher incidence of environmental policies and/or environmental commitments compared to low financial performance companies, while medium financial performance companies had the highest level of environmental policies and/or environmental commitments [39]. Nor et al. showed through empirical studies that there is a mixed result between the behavior of environmental disclosure and financial performance, and that environmental disclosure is significantly related to profitability [40].

Based on carbon disclosure perspective, Luo et al. investigated the actions of Fortune 500 companies in terms of carbon disclosure strategies in response to climate change challenges based on a 2009 report provided by Fortune 500 companies to the Carbon Disclosure Project (CDP), and found that economic pressures were significantly associated with the decision to disclose carbon [41]. Luo et al. also selected a sample of 2045 large firms from 15 countries and representing different industries, based on the reports provided by these firms to the Carbon Disclosure Project (CDP) in 2009, using profitability, leverage and growth as indicators of resource availability and the extent of firm participation in the CDP as indicators of the propensity to disclose carbon and conducting an empirical study for developing and developed countries, respectively. The study found that the propensity to disclose carbon is correlated with the indicator of resource availability and that this relationship is more significant in developing countries, suggesting that one of the reasons for the lack of committed carbon reductions and disclosure in these countries is the shortage of resources [42]. Matsumura et al. examined the impact of carbon emissions and voluntary disclosure of carbon emissions on firm value based on data on carbon emissions voluntarily disclosed by S\&P500 companies to CDP (Carbon Disclosure Project) from 2006 to 2008. The study showed a negative correlation between carbon emissions and firm value [43]. Zhao and Li based on the data of Chinese listed companies, scored the quality of carbon emission information content and concluded that the return on net assets was positively related to the quality of carbon information disclosure [44].Zhao and Yan took the listed companies in the heavy polluting industry in the 2008-2011 China CDP report as a sample and found that the carbon disclosure level of the selected sample companies was significantly positively correlated with financial performance [45]. Li and Shi divided the carbon information disclosure quality evaluation index into 10 dimensions to score and explore the correlation between the carbon disclosure quality and financial performance. The study found that the higher the quality of carbon information disclosure, the higher the financial performance and there is intertemporal in this impact, but the intertemporal impact has a downward trend year by year [46]. Ganda based on the annual carbon emission reports of South African companies from 2010-2015, using panel regression, the results of the study indicate that carbon disclosure is positively related to ROA (return on assets) but negatively related to MVA (market value added) [31]. Zhu conducted the study from the perspective of financial management, analyzed the possible influence of carbon tax policy on green financial performance, green financial activities, green financial accounting and financial information disclosure of microeconomic entity power companies based on specific cases [47]. Piesiewicz and Ciechan-Kujawa (2021) conducted the study on 57 published integrated reports of listed companies in Poland, contributed to the integrated reporting examination by identifying quantitative and qualitative gaps when applying Integrated Reporting standards and found insignificant differences in the analysis of completeness of disclosures in performance [48].

Most of the national scholars' explorations on the economic consequences of carbon information disclosure have gathered in the aspects of carbon information disclosure and corporate value, cost of capital, and decision usefulness. The discussion on how the level of carbon information disclosure affects financial performance is relatively lacking, and more often explores the relationship between the role of environmental information disclosure and social responsibility information disclosure on financial performance. In addition, the 
findings of the current available studies are widely divergent, with positive, negative, and uncorrelated results.

Frost found from an empirical analysis of 60 Australian firms, mainly in extractive services, that better performing firms are willing to disclose more environmental information than poorer performing firms [49]. Clakson et al. chose two different measures of firm performance, and the empirical results both indicate that environmental information disclosure has a positive effect on firm performance [50]. Al-Tuwaijri et al. found a positive relationship between environmental performance, environmental information disclosure and firm performance by taking environmental performance into account [51]. Jenkins and Yakovleva found a positive effect between the level of social responsibility disclosure and corporate value for a sample of ten global mining companies [52].

In contrast, there are some scholars have shown a negative or no correlation between environmental disclosure and financial performance of firms. Freedman and Jaggi explored the relationship between the level of pollution disclosure, pollution performance and economic performance of firms in highly polluting industries, and found that for the total sample, there was no correlation between their level of pollution disclosure and economic performance. While the results of the subsample showed that large companies with poor economic performance provided the most detailed pollution information, for smaller firms there was no correlation between economic performance and pollution disclosure [53]. Richardson and Welker used a sample of Canadian companies from 19901992, found a significant positive relationship between social disclosure and the cost of equity capital, a positive relationship that was mitigated among companies with better financial performance, where companies may will be financially penalized to some extent for having disclosed socially responsible information [54]. The findings of Johnson suggested that a firm's illegal or irresponsible attitude will hurt it financially and have a negative impact on the firm's financial performance, however, merely complying with legal requirements or undertaking sporadic social responsibility will not bring any financial advantage to the firm [55]. Stanny and Ely found that there was no significant correlation between carbon disclosure and investment, and carbon disclosure did not promote company performance [56]. Hsu and Wang find that because of the high cost of environmental responsibility, corporate disclosure of greenhouse gas emissions does not produce timely economic benefits and may reduce corporate competitiveness [57]. Plumlee et al. studied heavy polluting industries and general industries separately, and the empirical results showed that the polluting industries are negatively related to the level of environmental information disclosure and the financial performance of firms, while general industries show a positive relationship [58].

By sorting out and summarizing the findings of previous studies mentioned above, it can be found that although the number of literatures on financial performance research from the perspective of environmental information disclosure is relatively large, scholars still cannot reach a consistent research conclusion. On the one hand, it is because scholars choose different methods for environmental information disclosure indicators; on the other hand, given the different research objects selected, the research results also differ, for example, carbon intensive industries and carbon non-intensive industries cannot be confused due to different industry characteristics and different pressure in terms of regulation.

The impact on financial performance from the perspective of carbon information disclosure is rarely studied. There are some scholars pay more attention to carbon information disclosure, but most of the studies are on the impact factors related to carbon information disclosure, and few empirical studies involve the impact on current financial performance and whether it is deferred to the next period. Moreover, in previous studies, many scholars have scored carbon information disclosure based on whether to disclose or the number of disclosures, which is highly subjective. Given that the Carbon Disclosure Project (CDP) benefits from the guidance of PricewaterhouseCoopers, its scoring system is more comprehensive and more authoritative, and the data also has stronger depth and breadth. 
Therefore, this paper will use the Carbon Disclosure Leader Index published by CDP as a proxy variable for carbon disclosure in CDP reports.

\subsection{Theoretical Hypothesis}

Based on the voluntary disclosure theory, the cost and the credibility of the disclosed information are worth more notice since they are the private information that the company chooses to publish. Management tends to reveal information that is beneficial to increase the corporate value (e.g., lower greenhouse gas emissions) and conceal unfavorable information that reduces the corporate value (e.g., the failure to meet emission reduction target), and rational managers tend to hide unfavorable information disclosure. The value growth effect of sustainability disclosure has been proposed in many scholars' studies (Dhaliwal et al.; Clarkson et al.; De Villiers, Marques) [59-61]. In addition, according to the signaling theory, good information promotes the development of the enterprise and will bring potential economic benefits, however, bad news will hinder the development of the enterprise and is likely to reduce the financial performance of the firm in the current period. Therefore, based on the perspective of voluntary disclosure theory and signaling theory, this paper argues that enterprises with high quality of carbon disclosure have better financial performance.

In addition, since ten industries are covered in the sample companies selected in this paper, including energy industry, industrial industry, materials industry, consumer discretionary industry, consumer staples industry, financial industry, health care industry, information technology industry, telecommunications service industry, and public utilities industry. Given that carbon-intensive industries such as energy, industry, and materials face higher risks in terms of energy costs, climate change response, energy saving and emission reduction, they are more cautious in disclosing relevant data and take a relatively conservative stance on carbon disclosure. While for industries such as information technology and finance, the risk associated with data disclosure are relatively low, and they are more proactive in their own carbon disclosure and more confident in carbon emission reduction. Therefore, this paper combines the approach of Clarkson (2008) [50] and He [62] to divide the industry categories into two categories, namely, carbon-intensive industries (energy, industry, material industries, utilities) and non-carbon-intensive industries (the remaining six industries). This leads to hypotheses 1 and 2.

Hypotheses 1 (H1). In carbon-intensive industries, carbon disclosure can contribute to the improvement of the company's current financial performance.

Hypotheses 2 (H2). In non-carbon-intensive industries, carbon disclosure can contribute to the improvement of the company's current financial performance.

According to the signaling theory, information utilizers such as management have a time process of absorbing, thinking, and reflecting on receiving information until deciding. During this period, the investor must measure whether the identified information is useful, and if it is, then the investor needs to distinguish whether the information conveys a signal that is beneficial to the investment or not, and finally make a corresponding response. In addition, according to the stakeholder theory, not only the resource environment of the enterprise itself must be considered in the process, but also the opinions of other stakeholders at the moment. Therefore, the significant impact of carbon disclosure on the current period's financial performance, regardless of the industry, is likely not to happen overnight and this significant impact will be deferred to the next period. So, based on signaling theory and stake-holder theory, this paper proposes the following hypothesis 3.

Hypotheses 3 (H3). On the premise that carbon disclosure has a significant impact on the company's current financial performance, it will be extended to the next period. 


\section{Materials and Model Design}

\subsection{Sample Selection and Data Sources}

The samples selected for this study are the Fortune 500 companies involved in the CDP report from 2011-2018 because the publicly available data of Carbon Disclosure Leadership Index (CDLI) are only from 2011-2018, and the carbon disclosure behaviors of these companies are still at the forefront of the times as of now, which can help us to provide a basis for the empirical research by providing the Carbon Disclosure Leadership Index (CDLI) and carbon emissions date. In addition, in order to study the current and intertemporal impact of carbon disclosure on financial performance, the relevant financial performance data used in this article come from 2011-2018. The carbon disclosure data used in this article are all sourced from the Carbon Disclosure Project (CDP), which are aggregated and processed by the CDP project team based on the corporate response data collected online. The financial data used come from Wind Information, which are all collected and filtered manually. Companies without CDLI scores and those with incomplete or discontinuous financial data were excluded, there are 94 remaining companies with a total of 752 samples. The sample companies involve 10 different industries, and all industries are divided into two categories, namely, carbon-intensive industries (denoted as IND $=1$ ) and non-carbon-intensive industries (denoted as IND $=0$ ).

\subsection{Variable Selection}

\subsubsection{Measurement of Financial Performance}

There are many indicators of financial performance, such as return on assets (ROA), earnings per share (EPS), return on equity (ROE), Z-score proposed by Edward Altman, return on investment (ROI) and profit margin. Among them, ROA and ROE are financial performance indicators recognized by scholars all over the world. Based on previous research, this paper selects the return on assets (ROA) as a substitute variable for financial performance. This indicator can reflect the company's financial performance at an overall level, and its high or low level can directly reflect the company's financial status, will not be affected by the company's extraordinary events, and has the characteristics of being objective, universal, and easy to obtain. At the same time, ROA is also one of the most concerned financial indicators of corporate stakeholders and it has good comparability.

\subsubsection{Measurement of Carbon Disclosure}

Since the focus of our study is carbon, we use the Carbon Disclosure Leader Index (CDLI) to measure the degree or level of carbon disclosure based on content analysis. Most of the questions in the CDP questionnaire are two-choice questions. Participants who provided truthful information gave a "yes" (count as 1 point) or "no" (count as 0 point) answer, such as whether the company has an environmental committee.

The design and development of CDLI have received professional guidance from Pricewaterhouse Coopers, which is better than self-designed methods. Its scores can reflect the depth and breadth of corporate carbon information. By using a content analysis method that facilitates the analysis and interpretation of relevance, materiality, and substance of disclosure rather than simply the number of counts and the extend of disclosure, the CDLI score has also received widespread support at present.

\subsubsection{Measurement of Financial Performance}

Other control variables include net profit margin, debt to asset ratio, enterprise scale, growth rate of total operating income, etc. The specific variables are shown in Table 1: 
Table 1. Variable design.

\begin{tabular}{|c|c|c|c|}
\hline Variable Type & Variable Name & Symbol & Description \\
\hline Dependent Variable & Return on Assets & ROA & Return on Assets = Net Income $/$ Total Assets \\
\hline Independent Variable & Carbon Disclosure & CDLI & Carbon Disclosure Leader Index \\
\hline \multirow{7}{*}{ Control Variable } & Net Profit Margin & NPM & \multirow{7}{*}{$\begin{array}{c}\text { Net Profit Margin }=\text { Net Profit } / \text { Sales Revenue } \\
\text { Debt to Asset Ratio }=\text { Debt } / \text { Total Assets } \\
\text { Enterprise Scale }=\ln _{\text {Total Assets }} \\
\text { Growth Rate of Total Operating Income = } \\
\text { (Current Period Gross Operating Income } \\
\text { - Previous Period Gross Operating Income) } \\
\text { /Current Period Gross Operating Income }\end{array}$} \\
\hline & Debt to Asset Ratio & LEV & \\
\hline & Enterprise Scale & SIZE & \\
\hline & & & \\
\hline & Growth Rate of Total & GR & \\
\hline & Operating Income & & \\
\hline & & & \\
\hline Grouping Variable & $\begin{array}{l}\text { Whether belongs to carbon } \\
\text { intensive industry }\end{array}$ & IND & $\begin{array}{l}1 \text { for carbon-intensive industries and } 0 \text { for } \\
\text { non-carbon-intensive industries }\end{array}$ \\
\hline
\end{tabular}

\subsection{Regression Model Setting}

This paper investigates the impact of carbon disclosure on financial performance in carbon-intensive industries and non-carbon-intensive industries. The financial performance of the current period and the next period are used as explanatory variable and carbon disclosure is used as the explanatory variables. Stata16.0 is used as the multivariate statistical analysis software for this paper, and the following two multiple regression models are established:

$$
\begin{gathered}
\text { ROAt }=\mathrm{a} 0+\mathrm{a} 1 \text { CDLIt }+\mathrm{a} 2 \mathrm{NPMt}+\mathrm{a} 3 \mathrm{LEVt}+\mathrm{a} 4 \text { SIZEt }+\mathrm{a} 5 \mathrm{GRt}+\varepsilon . \\
\mathrm{ROAt}+1=\mathrm{a} 0+\mathrm{a} 1 \text { CDLIt }+\mathrm{a} 2 \mathrm{NPMt}+\mathrm{a} 3 \mathrm{LEVt}+\mathrm{a} 4 \text { SIZEt }+\mathrm{a} 5 \mathrm{GRt}+\varepsilon
\end{gathered}
$$

Among them, Model 1 is used to investigate the impact of carbon disclosure on financial performance in the current period, and Model 2 is used to study the impact of carbon disclosure on financial performance in the next period when carbon disclosure has a significant impact on the current period financial performance. Both models are suitable for empirical analysis of carbon-intensive industries, non-carbon-intensive industries, and full samples.

\section{Empirical Results and Analysis}

\subsection{Descriptive Statistics}

\subsubsection{Descriptive Statistical Analysis of the Full Sample}

There are 752 samples selected in this article, including 10 industry categories. The specific industry distribution is shown in Table 2 below:

Table 2. Classification of industries to which the full sample belongs.

\begin{tabular}{ccc}
\hline Category & Quantity & Proportion \\
\hline Energy & 112 & $14.89 \%$ \\
Industrial & 80 & $10.64 \%$ \\
Materials & 88 & $11.70 \%$ \\
Public Utilities & 40 & $5.32 \%$ \\
Consumer Discretionary & 40 & $5.32 \%$ \\
Consumer staples & 56 & $7.45 \%$ \\
Finance & 160 & $21.28 \%$ \\
Health Care & 80 & $10.64 \%$ \\
Information Technology & 64 & $8.51 \%$ \\
Telecommunication services & 32 & $4.26 \%$ \\
Total & 752 & $100 \%$ \\
\hline
\end{tabular}


As can be seen from Table 2 that the financial industry, energy industry, material industry, industrial industry, and health care industry account for a large proportion of the entire sample. The proportions are $21.28 \%, 14.89 \%, 11.70 \%, 10.64 \%$, and $10.64 \%$, respectively. Among them, there are 320 sub-samples of carbon-intensive industries (energy, materials, industrial and public utilities), accounting for a total of $42.55 \%$. Non-carbon-intensive industries (consumer discretionary, consumer staples, finance, health care, information technology, telecommunications services) has a total of 432 sub-samples, accounting for a total of $57.45 \%$.

Table 3 presents the minimum, maximum, average, and standard deviation of all variables in the full sample of 752 . The average return on assets (ROA) is 0.0883 , and the standard deviation is 0.0741 , indicating that the difference in the return on assets in the entire sample is not significant. The minimum value of carbon disclosure (CDLI) is 25 , the maximum value is 100 , the average value is 80.8546 , and the standard deviation is 14.1486 , indicating that there are large differences in carbon disclosure in the entire sample.

Table 3. Descriptive statistical analysis of the full sample variables.

\begin{tabular}{ccccc}
\hline & Minimum & Maximum & Average Value & $\begin{array}{c}\text { Standard } \\
\text { Deviation }\end{array}$ \\
\hline ROA & -0.2122 & 0.3344 & 0.0883 & 0.0741 \\
CDLI & 25.0000 & 100.0000 & 80.8546 & 14.1486 \\
NPM & -0.8475 & 0.4107 & 0.1102 & 0.1162 \\
LEV & 0.1578 & 0.9747 & 0.6472 & 0.2057 \\
SIZE & 22.4130 & 28.6619 & 25.1815 & 1.4681 \\
GR & -0.3216 & 2.9728 & 0.0913 & 0.2342 \\
\hline
\end{tabular}

\subsubsection{Descriptive Statistical Analysis of Sub-Samples}

Table 4 presents the minimum, maximum, average, and standard deviation of all variables in the carbon-intensive industries. The number of samples in this group is 320. The minimum value of return on assets (ROA) is -0.2122 and the maximum value is 0.3344 . The minimum value of carbon disclosure (CDLI) is 34 , the maximum value is 99 , the average value is 79.1833 , and the standard deviation is 14.3732 , indicating that the quality of carbon disclosure varies among companies.

Table 4. Descriptive statistical analysis of variables $(\mathrm{IND}=1)$.

\begin{tabular}{ccccc}
\hline & Minimum & Maximum & Average Value & Standard Deviation \\
\hline ROA & -0.2122 & 0.3344 & 0.0938 & 0.0698 \\
CDLI & 34.0000 & 99.0000 & 79.1833 & 14.3732 \\
NPM & -0.8475 & 0.4107 & 0.0841 & 0.1443 \\
LEV & 0.2654 & 0.9549 & 0.5741 & 0.1404 \\
SIZE & 23.1833 & 27.2987 & 24.7454 & 0.8002 \\
GR & -0.3216 & 2.9728 & 0.1224 & 0.3147 \\
\hline
\end{tabular}

Table 5 presents the minimum, maximum, average, and standard deviation of all variables in non-carbon-intensive industries. The number of samples in this group is 432. The minimum return on assets (ROA) is -0.0928 and the maximum is 0.3220 . The minimum carbon disclosure (CDLI) is 25 , the maximum is 100 , the average is 82.0926 , and the standard deviation is 13.8948 , indicating that the quality of carbon disclosure also varies among non-carbon-intensive industries. 
Table 5. Descriptive statistical analysis of variables $(\mathrm{IND}=0)$.

\begin{tabular}{ccccc}
\hline & Minimum & Maximum & Average Value & Standard Deviation \\
\hline ROA & -0.0928 & 0.3220 & 0.0843 & 0.0771 \\
CDLI & 25.0000 & 100.0000 & 82.0926 & 13.8948 \\
NPM & -0.1051 & 0.3551 & 0.1295 & 0.0855 \\
LEV & 0.1578 & 0.9747 & 0.7013 & 0.2287 \\
SIZE & 22.4130 & 28.6619 & 25.5046 & 1.7441 \\
GR & -0.2643 & 1.0015 & 0.0683 & 0.1459 \\
\hline
\end{tabular}

\subsubsection{Mean Difference}

Comparing the statistical values of the main variables in carbon-intensive industries and carbon-non-intensive industries, it can be seen from Table 6 that the average return on assets (ROA) are 0.0938 and 0.0843 , with the standard deviations of 0.0698 and 0.0771 , respectively. And the value of return on assets in the two groups of industries do not differ significantly. The mean values of carbon disclosure (CDLI) are 79.1833 and 82.0926, respectively, indicating that the average quality of carbon disclosure in non-carbon-intensive industries is higher, with the standard deviations of 14.3733213 .8948 , respectively. To further test whether the main variables are significantly different among different groups are, this paper adopts mean difference analysis to identify.

Table 6. Descriptive statistics for grouping of main variables.

\begin{tabular}{cccccc}
\hline & IND & N & Average & Standard Deviation & Standard Error of Mean \\
\hline \multirow{2}{*}{ ROA } & 1 & 320 & 0.0938 & 0.0698 & 0.0064 \\
& 0 & 432 & 0.0843 & 0.0771 & 0.0061 \\
\hline \multirow{2}{*}{ CDLI } & 1 & 320 & 79.1833 & 14.3732 & 1.3121 \\
& 0 & 432 & 82.0926 & 13.8948 & 1.0917 \\
\hline
\end{tabular}

As can be seen from Table 7 that the significance probability (Sig.) of the return on assets (ROA) is 0.2800 , that is, there is no significant difference in ROA between the two sub-samples. The carbon disclosure (CDLI) has the significance probability (Sig.) of is 0.0880 , which means there is a significant difference in CDLI between the two subsamples. Therefore, based on the above analysis, it is theoretical and scientific to group carbon-intensive industries (IND $=1$ ) and non-carbon-intensive industries (IND $=0$ ) for discussion.

Table 7. Comparison of differences in means between sub-samples.

\begin{tabular}{cccccc}
\hline & IND = 1 & IND = 0 & Difference in Mean & $\mathbf{t}$ & Sig. \\
\hline ROA & 0.0938 & 0.0843 & 0.0095 & 1.08 & 0.2800 \\
CDLI & 79.1833 & 82.0926 & -2.9093 & -1.71 & 0.0880 \\
\hline
\end{tabular}

Note: $t$-test using independent samples.

\subsection{Correlation Analysis between Carbon Disclosure and Current Financial Performance}

Tables 8 and 9 respectively present the correlation coefficients between the variables of carbon-intensive industries and carbon-non-intensive industries. Comparing the correlation coefficients in the two tables, it is found that the positive and negative signs of the correlation coefficients are consistent and do not differ significantly. In addition, the correlation coefficients between the control variables of debt to asset ratio (LEV) and enterprise scale (SIZE) are close to 0.5 in Table 8 and exceed 0.5 in Table 9. However, the multicollinearity results show that the VIF values of LEV and SIZE in Table 8 are 1.14 and 1.22, respectively, and the VIF values of LEV and SIZE in Table 9 are 2.33 and 2.28, respectively, which are far less than 10 . This indicates that there is no problem of multicollinearity in Model 1. 
Table 8. Correlation analysis between variables (IND $=1)$.

\begin{tabular}{ccccccc}
\hline & ROA & CD & NPM & LEV & SIZE & GR \\
\hline ROA & 1 & & & & & \\
CDLI & -0.1563 & 1 & & & & \\
NPM & $0.6409^{* *}$ & -0.1401 & 1 & & & \\
LEV & $-0.3000^{* *}$ & $0.2527^{* *}$ & -0.0694 & 1 & & \\
SIZE & -0.1645 & 0.0295 & -0.0282 & $0.3438^{* *}$ & 1 & 1 \\
GR & $0.2158^{*}$ & $-0.2912^{* *}$ & 0.1346 & -0.0175 & 0.0131 & 1 \\
\hline
\end{tabular}

Note: ${ }^{*}$ indicates that the two variables are significantly correlated at the $5 \%$ level, ${ }^{* *}$ indicates that the two variables are significantly correlated at the $1 \%$ level.

Table 9. Correlation analysis between variables (IND $=0)$.

\begin{tabular}{ccccccc}
\hline & ROA & CD & NPM & LEV & SIZE & GR \\
\hline ROA & 1 & & & & & \\
CDLI & $-0.1889^{*}$ & 1 & & & & \\
NPM & $0.4797^{* *}$ & $-0.2718^{* *}$ & 1 & & & \\
LEV & $-0.5098^{* *}$ & $0.2329^{* *}$ & $-0.2757^{* *}$ & 1 & & \\
SIZE & $-0.7362^{* *}$ & $0.3399^{* *}$ & $-0.2357^{* *}$ & $0.7357^{* *}$ & 1 & \\
GR & 0.1338 & -0.0356 & 0.1049 & $-0.2178^{* *}$ & $-0.1723^{*}$ & 1
\end{tabular}

Note: ${ }^{*}$ indicates that the two variables are significantly correlated at the $5 \%$ level, ${ }^{* *}$ indicates that the two variables are significantly correlated at the $1 \%$ level. Numbered lists can be added as follows.

\subsection{Regression Analysis}

4.3.1. Sub-Sample Regression Analysis

(1) The Impact of Carbon Disclosure on Current Financial Performance

The results of the regression analysis with carbon disclosure (CDLI) as the explanatory variable are presented in Tables 10 and 11 for the carbon-intensive and non-carbon-intensive industries, respectively.

Tables 10 and 11 respectively show the results of the regression analysis of carbonintensive industries and non-carbon-intensive industries with carbon disclosure (CDLI) as the explanatory variable. The adjusted $R^{2}$ values are 0.4761 and 0.6600 , respectively, indicating that the degree of explanation of the return on assets (ROA) of all independent variables in the two samples is $47.61 \%$ and $66.00 \%$, respectively. The $p$-value of Model 1 in both sets of samples was 0.0000 , indicating that Model 1 passed the significance test. In the group with carbon-intensive industries, the coefficient of carbon disclosure (CDLI) is 0.0157 , which is positive but does not pass the significance test. Therefore, the hypothesis $\mathrm{H} 1$ has not been verified. However, in the group of non-carbon-intensive industries, the coefficient of carbon disclosure (CDLI) is 0.0009 with a $p$-value of 0.0010 , indicating a significant correlation at the $1 \%$ level. Therefore, the hypothesis of $\mathrm{H} 2$ is verified.

Table 10. Regression analysis with CDLI as explanatory variable (IND = 1).

\begin{tabular}{cccc}
\hline Variable & Coefficient & t-Value & $p$-Value \\
\hline CDLI & 0.0157 & 0.48 & 0.6330 \\
NPM & $0.2940^{* * *}$ & 7.83 & 0.0000 \\
LEV & $-0.1194^{* * *}$ & -2.68 & 0.0090 \\
SIZE & -0.00589 & -0.86 & 0.3900 \\
GR & $0.03107^{* * *}$ & 3.26 & 0.0010 \\
Constant term & 0.26702 & 1.54 & 0.1270 \\
Adjusted $R^{2}$ & & 0.4761 & \\
F-statistic of the model & & 15.18 & \\
Sig. & 0.0000 & \\
Number of samples & 320 &
\end{tabular}

Note: ${ }^{* * *}$ indicate that the two variables are significantly correlated at the $1 \%$ level. 
Table 11. Regression analysis with CDLI as explanatory variable (IND $=0$ ).

\begin{tabular}{cccc}
\hline Variable & Coefficient & t-Value & $p$-Value \\
\hline CDLI & $0.0009^{* * *}$ & 3.39 & 0.0010 \\
NPM & $0.3362^{* * *}$ & 6.50 & 0.0000 \\
LEV & $0.0529^{*}$ & 1.75 & 0.0830 \\
SIZE & $-0.0361^{* * *}$ & -8.08 & 0.0000 \\
GR & -0.0034 & -0.13 & 0.8990 \\
Constant term & $0.8556^{* * *}$ & 9.47 & 0.0000 \\
Adjusted ${ }^{2}$ & & 0.6600 & \\
F- statistic of the model & & 58.77 & \\
Sig. & & 0.0000 & \\
Number of samples & & 432 &
\end{tabular}
Note: ${ }^{*}, * *$ indicate that the two variables are significantly correlated at the $10 \%$ and $1 \%$ level.

(2) The Intertemporal Impact of Carbon Disclosure on Financial Performance

It can be seen from the above that $\mathrm{H} 2$ has been verified, that is, in non-carbon-intensive industries, carbon disclosure has a significant positive impact on current period financial performance. Therefore, this paper will further investigate the intertemporal effects of various explanatory variables on next period financial performance based on this hypothesis.

As can be seen from Table 12 that the coefficient of Carbon Disclosure (CDLI) is 0.0008 (slightly smaller than the coefficient of 0.0009 in Table 11), but its $p$-value is 0.0030 , which is significant at the $1 \%$ level, the same level of significance as in Table 11 . Therefore, the positive impact of carbon disclosure on financial performance can be extended to the next period, and hypothesis $\mathrm{H} 3$ is thus verified.

Table 12. The intertemporal impact of carbon disclosure on financial performance (IND $=0$ ).

\begin{tabular}{cccc}
\hline Variable & Coefficient & t-Value & $p$-Value \\
\hline CDLI & $0.0008^{* * *}$ & 2.99 & 0.0030 \\
NPM & $0.2644^{* * *}$ & 5.39 & 0.0000 \\
LEV & $0.0615^{*}$ & 1.97 & 0.0510 \\
SIZE & $-0.0367^{* * *}$ & -7.84 & 0.0000 \\
GR & -0.0229 & -0.71 & 0.4810 \\
Constant term & $0.8768^{* * *}$ & 9.19 & 0.0000 \\
Adjusted ${ }^{2}$ & & 0.6034 & \\
F-statistic of the & & 51.88 & \\
model & & 0.0000 & \\
Sig. & & 432 & \\
Number of samples & &
\end{tabular}

Note: ${ }^{*}{ }^{* * *}$ indicate that the two variables are significantly correlated at the $10 \%$ and $1 \%$ level.

\subsubsection{Full Sample Regression Analysis}

In order to compare with the regression results of the sub-samples after grouping, the regression analysis for the full sample is also conducted and the result is briefly summarized in Table 13. From which it can be seen that, unlike the sub-sample companies, carbon disclosure and financial performance are not significantly correlated for the full sample companies, thus further verifying the necessity of group research as described above.

Table 13. Regression analysis for the full sample.

\begin{tabular}{cccccccc}
\hline Model & Number of Samples & Sig. & Adjusted $\mathbf{R}^{\mathbf{2}}$ & Variable & Coefficient & $\mathbf{t}$-Value & $\boldsymbol{p}$-Value \\
\hline Model 1 & 752 & 0.0000 & 0.5537 & CDLI & 0.0003 & 1.40 & 0.1630 \\
\hline
\end{tabular}




\subsection{Robustness Test}

In this paper, the return on equity (ROE) is chosen as a substitute variable for financial performance to do the robustness test. According to the classic DuPont analysis system, it is known that $\mathrm{ROE}=\mathrm{ROA}^{*} 1 /(1-$ debt ratio), so the return on equity (ROE) and return on assets (ROA) is relatively close, and the regression results are expected to be consistent when the two are used as explanatory variables. The results of robustness test are shown in Table 14.

Table 14. Robustness test results.

\begin{tabular}{|c|c|c|c|}
\hline \multirow[t]{2}{*}{ Variable } & \multicolumn{2}{|c|}{ Model 1} & \multirow{2}{*}{$\begin{array}{l}\text { Model } 2 \\
\text { IND }=0\end{array}$} \\
\hline & IND = 1 & $\mathrm{IND}=0$ & \\
\hline \multirow{2}{*}{ CDLI } & 0.0005 & -0.0008 & $0.0023^{* *}$ \\
\hline & $(0.83)$ & $(-0.23)$ & (2.42) \\
\hline \multirow{2}{*}{ NPM } & $0.5679 * * *$ & $0.8411^{* * *}$ & $0.7596^{* * *}$ \\
\hline & (3.97) & $(4.62)$ & $(5.16)$ \\
\hline \multirow{2}{*}{ LEV } & $0.5662 * * *$ & $0.8613^{* * *}$ & $0.8378^{* * *}$ \\
\hline & $(2.84)$ & $(5.17)$ & $(5.50)$ \\
\hline \multirow{2}{*}{ SIZE } & $-0.0287^{* *}$ & $-0.1236^{* * *}$ & $-0.1387^{* * *}$ \\
\hline & $(-2.05)$ & $(-6.99)$ & $(-6.68)$ \\
\hline \multirow{2}{*}{ GR } & $0.0346^{* *}$ & -0.0154 & -0.1250 \\
\hline & $(2.11)$ & $(-0.22)$ & $(-1.47)$ \\
\hline \multirow{2}{*}{ Constant term } & 0.4468 & $2.7141^{* * *}$ & $2.8638^{* * *}$ \\
\hline & $(1.37)$ & $(6.63)$ & $(6.88)$ \\
\hline Adjusted R2 & 0.3764 & 0.2958 & 0.4827 \\
\hline F-statistic of the model & 4.85 & 17.77 & 18.78 \\
\hline Sig. & 0.0005 & 0.0000 & 0.0000 \\
\hline Number of samples & 320 & 432 & 432 \\
\hline
\end{tabular}

Note: ${ }^{* *}{ }^{* * *}$ indicate that the two variables are significantly correlated at the $5 \%$ and $1 \%$ level.

For carbon-intensive industries, when ROE is used as a surrogate variable for financial performance, the sign and significance level of the regression coefficient are almost the same as when the return on assets (ROA) is used as the explained variable, that is, although the regression coefficient of carbon disclosure (CDLI) is positive, it has not passed the significance test, which is completely consistent with the regression analysis above.

In non-carbon-intensive industries, when ROE is used as a substitute variable for financial performance, the regression coefficients of key variables are consistent with the above regression results, but the significance level is slightly different. The regression coefficient of carbon disclosure (CDLI) is still positive, but at a lower level of significance compared to using return on assets (ROA) as a financial performance.

In addition, when ROEt +1 is used as an alternative for the financial performance in the model, the positive impact of carbon disclosure on financial performance will have a significant contribution to financial performance in the next period and is significant at the $5 \%$ level.

In conclusion, when the return on equity (ROE) is used as a substitute variable for financial performance, the analysis results of all the main variables of the model in this article are still valid and pass the robustness test.

\section{Discussion and Conclusions}

Based on previous research and theoretical foundations, this paper combines the average and distribution characteristics of carbon disclosure and divides the sample enterprises into two groups, namely carbon-intensive enterprises, and non-carbon-intensive enterprises, to investigate the impact of carbon disclosure on the current financial performance and whether the significant impact on the current financial performance will be deferred to the next period in these two groups of companies. As this article selects the Fortune 500 companies, which are of great concern to the public. Beside this, these companies have made great contributions to environmental issues and can be regarded as leaders in 
carbon disclosure. And they have a relatively comprehensive understanding of carbon management, which they have implemented and integrated into their corporate culture, providing practical experience for the implementation of carbon emission reduction to the world. Based on the combination of theory and previous empirical research, this article draws the following research conclusions.

In carbon-intensive industries, although carbon disclosure by the company can promote the improvement of financial performance in the current period, the improvement is small, and it does not pass the significance test. This indicates that the improvement in the quality of carbon disclosure of carbon-intensive companies has a relatively small impact on financial performance. The company has not been greatly rewarded for its high-quality carbon disclosure behavior, and the impact of the carbon disclosure on their current financial performance is still limited despite the high evaluation of their carbon management from the public.

In non-carbon-intensive industries, the carbon disclosure of company can significantly contribute to the improvement of financial performance in the current period. The higher the quality of carbon disclosure, the better the financial performance of the company, and the impact of carbon disclosure on current financial performance can be extended to the next period. Through the analysis of carbon disclosure data, it can be seen that many non-carbon-intensive companies actively respond to the development of low-carbon economy. Taking the financial industry as an example, as a leader in carbon emission reduction in this industry, they vigorously implement carbon strategies and advocate green development of enterprises. Based on the conclusions, non-carbon-intensive industries can get better financial performance with carbon disclosure and this impact will last to the next period. However, in carbon-intensive industries, the improvement of financial performance by discoursing carbon information is small. This can also how that despite the disclosure of carbon information, based on the carbon-intensive characteristics, these companies do not necessarily get better financial performance from disclosing carbon information, which means that carbon-intensive industries also need to achieve the goal of attracting stakeholders by developing low-carbon awareness and reducing carbon emissions. For carbon-non-intensive industries, in order to obtain better financial performance, they should continue to maintain the behavior of disclosing carbon information.

The paper has deepened the understanding of carbon disclosure by enterprises from the theoretical level, which has certain significance for the practice of carbon disclosure of Chinese enterprises, and also promotes the development of empirical research related to carbon disclosure. At the same time, the empirical research in this paper also makes up for the deficiencies of existing research as few scholars have studied whether the significant impact of carbon disclosure on financial performance is deferred to the next period and few scholars have conducted comparative analysis of for carbon-intensive industries and carbon-non-intensive industries. Therefore, this research investigates the impact of carbon disclosure on current financial performance for carbon-intensive industries and carbon-non-intensive industries, and on this basis, the inter-temporal impact of carbon disclosure on financial performance.

Since this paper takes the world's top 500 enterprises as the research object, these enterprises have already had a fairly high awareness of carbon management in terms of carbon information disclosure, the conclusions obtained are not applicable to all enterprises though. However, under the global trend of promoting low carbon development, the study has certain guiding significance, and the Top 500 enterprises have played an exemplary role, which is worth learning from for other countries' enterprises such as China. To this end, this paper proposes the following policy recommendations based on the above findings.

(1) Increase publicity and raise low carbon awareness.

Take China as an example, from the situation of the world's top 500 and China's top 100 enterprises for CDP response, China's top 100 enterprises are less conscious of carbon information disclosure, which shows that for other Chinese enterprises, low carbon awareness is quite weak and will seriously hinder China's vision to achieve carbon emission 
reduction. Low carbon awareness is the first thing that needs to be advocated, because only by forming low carbon awareness can we take action to reduce carbon emissions and carry out carbon management, achieve sustainable development of enterprises, jointly create a green development atmosphere, avoid the risks brought about by climate change, seize the opportunities of low carbon development, and be brave enough to take on the challenges to achieve a virtuous cycle of low carbon economy.

(2) Improve laws and regulations and regulate carbon disclosure channels.

Laws and regulations are the basis for enterprises to regulate their behavior. In the absence of sound laws and regulations, enterprises often pursue short-term interests at the expense of the environment, which will cause serious damage to the environment in the long run. Although public opinion, media attention, etc. will, to a certain extent, prompt enterprises to disclose carbon information, but their roles are limited. Laws and regulations are the boundaries that enterprises cannot cross, mandatory application of carbon emission reduction targets or disclosure of carbon information to guide the behavior of enterprises are more effective. In addition, the government should also increase the rewards for enterprises that independently disclose carbon information and achieve the emission reduction target or even exceed the emission reduction target, and formulate a standardized incentive policy, while those that violate the relevant laws and regulations should be strictly punished, so as to strengthen enterprises' awareness of the initiative to disclose carbon emissions and cultivate their sense of social responsibility in the legal system.

(3) Establish a unified carbon information disclosure system.

For example, at present, there is no unified carbon information disclosure system in China. Although some enterprises are conscious of reducing their carbon emissions, the accounting methods among enterprises are different and not comparable, and the evaluation standards among enterprises are also different. The complex assessment procedures and the lack of comparability, even with information lacking authenticity, will not only confuse the judgment of corporate investors and mislead corporate investments, but also discourage corporate compliance with the principles of low-carbon development. For example, companies may reduce their carbon emission statistics by changing their carbon emission accounting methods. Therefore, the government should gradually establish a unified carbon information disclosure system and develop a standard and unified accounting method, so that every enterprise can have evidence to follow and evidence to rely on, and investors and other relevant stakeholders can also benefit from it, so that every enterprise can pay close attention to its own carbon emissions and lay the foundation for the national carbon emission reduction target.

(4) Standardize the way of carbon information disclosure in CDP reports.

Because carbon information disclosure has shifted from a voluntary to a mandatory requirement in many jurisdictions, the format and content of CDP reports could be considered to be formulated as a formal GHG statement. Based on our research analysis, we observe that there is room for improvement in the current version of the CDP report. For example, we believe that there should be industry-specific disclosure guidelines and that there should be more information disclosure at the project level. In addition, companies need to upgrade their accounting systems to match the current needs of the low carbon economy.

As the paper mentioned before, although previous studies have been conducted to find the relationship between carbon disclosure and financial performance, and the number of literatures on financial performance research from the perspective of environmental information disclosure is relatively large, scholars still cannot reach a consistent research conclusion. One of the reasons for this situation can be attributed to the lack of a unified carbon information disclosure index. If the above-mentioned suggestions are adopted, the establishment of a unified carbon information disclosure system and standardization of the carbon information disclosure method in the CDP report can effectively resolve this problem. Coupled with the guidance and regulation of laws and regulations, companies with higher low-carbon ceremonies will consciously and proactively disclose carbon infor- 
mation in accordance with the normative model, which can also provide better indicator choices for relevant research. Besides, on the basis of being able to obtain uniform and standardized carbon information disclosure measurement indicators, scholars can choose more different research subjects to study the relationship between carbon disclosure and financial performance and. While at the same time, because of the consistency of indicators measurement methods, the results of all these studies will become more comparable to provide the impact of carbon disclosure on financial performance among different industries in the future.

Author Contributions: Conceptualization, N.Z. and J.Z.; methodology, W.L. and N.Z.; software, J.Z. and W.L.; validation, W.L. and J.Z.; formal analysis, J.Z. and W.L.; investigation, W.L.; resources, W.L.; data curation, W.L. and J.Z.; writing-original draft preparation, W.L. and J.Z.; writing-review and editing, W.L.; visualization, W.L. and J.Z.; supervision, N.Z.; project administration, N.Z.; funding acquisition, N.Z. All authors have read and agreed to the published version of the manuscript.

Funding: This research received no external funding.

Institutional Review Board Statement: Not applicable.

Informed Consent Statement: Not applicable.

Data Availability Statement: The carbon disclosure data used in this article are all sourced from the Carbon Disclosure Project (CDP), available at https://www.cdp.net/ (accessed on 15 June 2021). The financial data used come from Wind Information, available at https:/ / www.wind.com.cn/ (accessed on 15 June 2021).

Acknowledgments: This work was supported by the National Social Science Fund of China (Grant No. 20BGL099).

Conflicts of Interest: The authors declare no conflict of interest.

\section{References}

1. Liu, Y.; Zhou, Z.; Zhang, X.; Xu, X.; Chen, H.; Xiong, Z. Net global warming potential and greenhouse gas intensity from the double rice system with integrated soil-crop system management: A three-year field study. Atmos. Environ. 2015, 116, 92-101. [CrossRef]

2. Sands, F. The United Nations framework convention on climate change. Rev. Eur. Community Int. Environ. Law 1992, 1, 270. [CrossRef]

3. Stocker, T.F.; Qin, D.; Plattner, G.-K.; Tignor, M.; Allen, S.K.; Boschung, J.; Nauels, A.; Xia, Y.; Bex, V.; Midgley, P.M. IPCC, 2013: Climate Change 2013: The Physical Science Basis. Contribution of Working Group I to the Fifth Assessment Report of the Intergovernmental Panel on Climate Change. Available online: https://www.ipcc.ch/report/ar5/wg1/ (accessed on 15 June 2021).

4. Global Warming of $1.5^{\circ} \mathrm{C}$. Available online: https://www.ipcc.ch/sr15/ (accessed on 15 June 2021).

5. The Global Risks Report. 2020. Available online: https://www.weforum.org/reports/the-global-risks-report\$-\$2020 (accessed on 15 June 2021).

6. Luo, L. The influence of institutional contexts on the relationship between voluntary carbon disclosure and carbon emission performance. Account. Financ. 2019, 59, 1235-1264. [CrossRef]

7. Li, D.; Huang, M.; Ren, S.; Chen, X.; Ning, L. Environmental legitimacy, green innovation, and corporate carbon disclosure: Evidence from CDP China 100. J. Bus. Ethics 2018, 150, 1089-1104. [CrossRef]

8. Meng, X.H.; Zeng, S.X.; Shi, J.J.; Qi, G.Y.; Zhang, Z.B. The relationship between corporate environmental performance and environmental disclosure: An empirical study in China. J. Environ. Manag. 2014, 145, 357-367. [CrossRef] [PubMed]

9. Zhu, N.; Qian, L.; Jiang, D.; Mbroh, N. A simulation study of China's imposing carbon tax against American carbon tariffs. J. Clean. Prod. 2020, 243, 118467. [CrossRef]

10. Liu, L. A Study on Corporate Carbon Emission Information Disclosure Model. Commun. Financ. Account. 2015, 16, 23-26.

11. Hahn, R.; Reimsbach, D.; Schiemann, F. Organizations, climate change, and transparency: Reviewing the literature on carbon disclosure. Organ. Environ. 2015, 28, 80-102. [CrossRef]

12. Uyar, A.; Karaman, A.S.; Kilic, M. Is corporate social responsibility reporting a tool of signaling or greenwashing? Evidence from the worldwide logistics sector. J. Clean. Prod. 2020, 253, 119997. [CrossRef]

13. Mobley, S.C. The Challenges of Socio-Economic Accounting. Account. Rev. 1970, 45, 762-768.

14. Gray, R.; Owen, D.; Maunders, K. Corporate Social Reporting: Emerging Trends in Accountability and the Social Contract. Account. Audit. Account. J. 1988, 1, 6-20. [CrossRef] 
15. Friedman, M. The Social Responsibility of Business is to Increase Its Profit. The New York Times Magazine, 13 September 1970; 122-126.

16. Deegan, C.; Gordon, B. A Study of the Environmental Disclosure Practices of Australian Corporations. Account. Bus. Res. 1996, 26, 187-199. [CrossRef]

17. Karim, K.E.; Lacina, M.J.; Rutledge, R.W. The Association between Firm Characteristics and the Level of Environmental Disclosure in Financial Statement Footnotes. Adv. Environ. Account. Manag. 2006, 3, 77-109.

18. Dhaliwal, D.; Radhakrishnan, S.; Tsang, A.; Yong, G.Y. Nonfinancial Disclosure and Analyst Forecast Accuracy: International Evidence on Corporate Social Responsibility Disclosure. Account. Rev. 2012, 87, 723-759. [CrossRef]

19. Lys, T.; Naughton, J.P.; Wang, C. Signaling Through Corporate Accountability Reporting. SSRN Electron. J. 2015, 60, 56-72. [CrossRef]

20. Hoi, C.K.; Zhang, H. Is Corporate Social Responsibility (CSR) Associated with Tax Avoidance? Evidence from Irresponsible CSR activities. Account. Rev. 2013, 88, 2025-2059. [CrossRef]

21. Hassel, L.; Nilsson, H.; Nyquist, S. The Value Relevance of Environmental Performance. Eur. Account. Rev. $2005,14,41-61$. [CrossRef]

22. Chapple, L.; Clarkson, P.M.; Gold, D.L. The Cost of Carbon: Capital Market Effects of the Proposed Emission Trading Scheme (ETS). Abacus 2013, 49,1-33. [CrossRef]

23. Griffin, P.A.; Lont, D.H.; Sun, E.Y. The Relevance to Investors of Greenhouse Gas Emission Disclosures. Contemp. Account. Res. 2017, 34, 1265-1297. [CrossRef]

24. Saka, C.; Oshika, T. Disclosure effects, carbon emissions and corporate value. Sustain. Account. Manag. Policy J. 2014, 5, 22-45. [CrossRef]

25. Velte, P.; Stawinoga, M.; Lueg, R. Carbon performance and disclosure: A systematic review of governance-related determinants and financial consequences. J. Clean. Prod. 2020, 254, 120063. [CrossRef]

26. Lemma, T.T.; Feedman, M.; Mlilo, M.; Park, J.D. Corporate carbon risk, voluntary disclosure, and cost of capital: South African evidence. Bus. Strategy Environ. 2019, 28, 111-126. [CrossRef]

27. Lueg, K.; Krastev, B.; Lueg, R. Bidirectional effects between organizational sustainability disclosure and risk. J. Clean. Prod. 2019, 229, 268-277. [CrossRef]

28. Wegener, M. The Carbon Disclosure Project, an Evolution in International Environmental Corporate Governance: Motivations and Determinants of Market Response to Voluntary Disclosures. Master's Thesis, Brock University, St. Catharines, ON, Canada, 2010.

29. Ziegler, A.; Busch, T.; Hoffmann, V.H. Disclosed corporate responses to climate change and stock performance: An international empirical analysis. Energy Econ. 2011, 33, 1283-1294. [CrossRef]

30. Schiager, H.; Haukvik, G.D. The Effect of Voluntary Environmental Disclosure on Firm Value: A Study of Nordic Listed Firms. Master's Thesis, Norges Handelshøyskole School, Bergen, Norway, 2012.

31. Ganda, F. The influence of carbon emissions disclosure on company financial value in an emerging economy. Environ. Dev. Sustain. 2018, 20, 1723-1738. [CrossRef]

32. Iskandar, D.; Fran, E. The Effect of Carbon Emissions Disclosure and Corporate Social Responsibility on the Firm Value with Environmental Performance as Variable Control. Res. J. Financ. Account. 2016, 7, 9.

33. Siddique, A.; Akhtaruzzaman, M.; Rashid, A.; Hammami, H. Carbon disclosure, carbon performance and financial performance: International evidence. Int. Rev. Financ. Anal. 2021, 75, 101734. [CrossRef]

34. Borghei, Z.; Leung, P.; Guthrie, J. Voluntary greenhouse gas emission disclosure impacts on accounting-based performance: Australian evidence. Australas. J. Environ. Manag. 2018, 25, 321-338. [CrossRef]

35. Brouwers, R.; Schoubben, F.; Cynthia Van Hulle, C.V. The influence of carbon cost pass through on the link between carbon emission and corporate financial performance in the context of the European Union Emission Trading Scheme. Bus. Strategy Environ. 2018, 27, 1422-1436. [CrossRef]

36. Freedman, M.; Jaggi, B. An analysis of the association between pollution disclosure and economic performance. Account. Audit. Account. J. 1988, 1, 43-58. [CrossRef]

37. Murray, A.; Sinclair, D.; Power, D.; Gray, R. Do Financial Markets Care About Social and Environmental Disclosure? Account. Audit. Account. J. 2006, 19, 228-255. [CrossRef]

38. Anderson, J.; Frankle, A. Voluntary Social Reporting an Iso-Beta Portfolio Analysis. Account. Rev. 1980, 19, 467-479.

39. Stanwick, S.D.; Stanwick, P.A. The relationship between environmental disclosures and financial performance: An empirical study of US firms. Corp. Soc. Responsib. Environ. Manag. 2000, 7, 155-164. [CrossRef]

40. Nor, N.M.; Bahari, N.A.; Adnan, N.A.; Kamal, S.M.; Ali, I.M. The Effects of Environmental Disclosure on Financial Performance in Malaysia. Procedia Econ. Financ. 2016, 35, 117-126. [CrossRef]

41. Luo, L.; Lan, Y.C.; Tang, Q. Corporate incentives to disclose carbon information: Evidence from the CDP Global 500 report. J. Int. Financ. Manag. Account. 2012, 23, 93-120. [CrossRef]

42. Luo, L.; Tang, Q.; Lan, Y.C. Comparison of propensity for carbon disclosure between developing and developed countries: A resource constraint perspective. Account. Res. J. 2013, 26, 6-34. [CrossRef]

43. Matsumura, E.M.; Prakash, R.; Vera-Muñoz, S.C. Firm-value effects of carbon emissions and carbon disclosures. Account. Rev. 2013, 89, 695-724. [CrossRef] 
44. Zhao, X.M.; Li, Y.Y. The Company Performance and the Information Disclosure Quality of Carbon Emission- From the Evidence of China's Listed Enterprises. J. Xi'an Shiyou Univ. 2013, 22, 22-27.

45. Zhao, X.; Yan, G. Business Performance and Carbon Disclosure Level in Heavy Polluting Industries: An Empirical Study Based on CDP China Report 2008-2011. Commun. Financ. Account. 2014, 18, 68-70.

46. Li, X.; Shi, Y. The Impact of the Quality of Carbon Information Disclosure on Corporate Financial Performance in the Concept of Green Development. Econ. Manag. 2016, 7, 119-132.

47. Zhu, N.; Bu, Y.; Jin, M.; Mbroh, N. Green financial behavior and green development strategy of Chinese power companies in the context of carbon tax. J. Clean. Prod. 2020, 245, 118908. [CrossRef]

48. Piesiewicz, M.; Ciechan-Kujawa, M.; Kufel, P. Differences in Disclosure of Integrated Reports at Energy and Non-Energy Companies. Energies 2021, 14, 1253. [CrossRef]

49. Frost, G.R.; Wilmshurst, T.D. Corporate environmental reporting: A test of legitimacy theory. Account. Audit. Account. J. 2000, 13, $10-26$.

50. Clarkson, P.M.; Li, Y.; Richardson, G.D.; Vasvari, F.P. Revisiting the relation between environmental performance and environmental disclosure: An empirical analysis. Account. Organ. Soc. 2008, 33, 303-327. [CrossRef]

51. Al-Tuwaijri, S.A.; Christensen, T.E.; Hughes, K.I. The relations among environmental disclosure, environmental performance, and economic performance: A simultaneous equations approach. Soc. Sci. Electron. Publ. 2004, 29, 447-471. [CrossRef]

52. Jenkins, H.; Yakovleva, N. Corporate Social Responsibility in the Mining Industry: Exploring Trends in Social and Environmental Disclosure. J. Clean. Prod. 2004, 14, 274-284. [CrossRef]

53. Freedman, M.; Jaggi, B. Pollution disclosures, pollution performance and economic performance. Omega 1982, 10, 167-176. [CrossRef]

54. Richardson, A.J.; Welker, M. Social disclosure, financial disclosure and the cost of equity capital. Account. Organ. Soc. 2001, 26, 597-616. [CrossRef]

55. Johnson, H.H. Does it pay to be good? Social responsibility and financial performance. Bus. Horiz. 2003, 46, 34-40. [CrossRef]

56. Stanny, E.; Ely, K. Corporate Environmental Disclosures about the Effects of Climate Change. Corp. Soc. Responsib. Environ. Manag. 2008, 15, 338-348. [CrossRef]

57. Hsu, A.W.; Wang, T. Does the market value corporate response to climate change? Omega 2013, 41, 195-206. [CrossRef]

58. Plumlee, M.; Marshall, S.; Brown, D. Voluntary Environmental Disclosure Quality and Firm Value. Roles of Venue and Industry Type. Soc. Sci. Electron. Publ. 2009, 34, 336-361.

59. Dhaliwal, D.S.; Li, O.Z.; Tsang, A.; Yang, Y.G. Voluntary nonfinancial disclosure and the cost of equity capital: The initiation of corporate social responsibility reporting. Account. Rev. 2011, 86, 59-100. [CrossRef]

60. Clarkson, P.M.; Fang, X.; Li, Y.; Richardson, G. The relevance of environmental disclosures: Are such disclosures incrementally informative? J. Account. Public Policy 2013, 32, 410-431. [CrossRef]

61. De Villiers, C.; Marques, A. Corporate social responsibility, country-level predispositions, and the consequences of choosing a level of disclosure. Account. Bus. Res. 2016, 46, 167-195. [CrossRef]

62. He, Y.; Tian, Q.; Wang, K. Carbon Disclosure, Carbon Performance, and Cost of Capital. Account. Res. 2014, 1, 79-86, 95. [CrossRef] 